\title{
POLITICAL MARKETING PLAN FOR ASPIRING NATIONAL COUNCIL CANDIDATURE
}

\author{
Damcho Gyeltshen \\ Master of Business Administration (MBA), Specialization in International Business Management \\ Stamford International University, Member of Laurate, Thailand
}

Abstract - The political marketing plan is mandated to execute in real life as a document that could benefit the candidate in political journey of election. The aim of this research is to develop a marketing plan $\&$ brand that serve as a guiding tool for the candidature by evaluating the political market through ascertaining of eligible voters in district level in Bhutan and evaluate the values, needs and wants of eligible voters there by strategically plan to develop an effective strategy to fulfil the needs and wants of electorates. This studies have used both primary data and secondary data research. As a primary data collection, an online computer assist survey through google form are used in understanding the electorates needs and wants, their problems, the benefits that they expect from the candidate and ultimately an effective promotion tools that the candidate could adopt between electorates and the politician in developing effective marketing strategy. It is to fulfil the public needs and wants and formulate the plan and a brand that could possibly serve as a guiding tool for the national council candidature. The secondary data are collected from focused group and TDI (Telephone in-depth interview) in understanding better insight about the public needs and wants

Subsequently, the content analysis pertaining to webpage, journals, e-books, annual reports, u-tube are used as a supplementary data required for the research. Based on the data collection result, the findings are ascertained and every results are evaluated and analyzed in depicting the appropriate target segment and came up with strategic political plan to promote the candidate as a brand and product in a market. Through the empirical research, It indicated that public aspire their political needs as two core distinct category, the candidate profile and the candidate pledges. As a candidate profile, they aspire to have skilled, highly qualified, experience as a mandatory requirement of candidate and the candidate pledges should not contravene with the needs and wants of a public where every pledges should have realization on candidate capacity and potential, the roles and responsibility of national council and the pledges that could potentially solve the public issues through effective communication channel. Overall, this plan would serve as a guiding tools for author as an aspiring national council candidature in future election

Keywords - Parliamentary election, National Council candidature, Candidate as a brand and product, Politician, Political brand and a market

\section{GENERALITIES OF STUDIES}

"Political marketing is the intrinsic product of marriage between the political science and the marketing theory" (Lilleker,2013). The domain and concept of marketing the product of goods and services has been shifted to political marketing in this era of electoral evolution. The evolution of electoral roles has been driven by the form of government in every country in a world as democratic system of government where the voting and election becomes inseparable phenomenon in the lives of every people all over the world. Despite which, it was an alarming fact to be noted that the present sphere of world is driven by the democratic government where there are 195 countries in a world and out of which 167 countries are democratic in different form of its nature categorized by the types of regimes and 19 countries are full democracy, 57 are flawed democracy, 39 are hybrid democracy and 52 are authoritarian regimes whereby proportion of $80.64 \%$ countries in a world is administered by the democratic form of government. (Harris, 2019). So, this era is all driven by the political form of government through election as the nature of country does not restrict on monarchy revolution as the evolution of political election is at the peak of popularity in every country in the world

Diagram 1; Democracy index 2017 


\section{International Journal of Engineering Applied Sciences and Technology, 2021 Vol. 6, Issue 2, ISSN No. 2455-2143, Pages 111-127 \\ Published Online June 2021 in IJEAST (http://www.ijeast.com)}

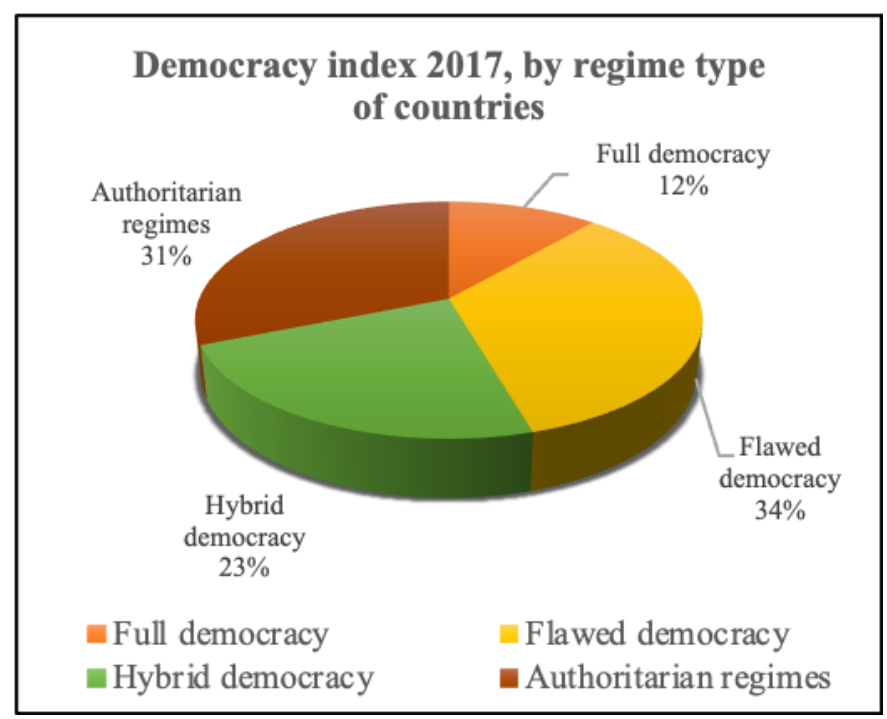

Sources: (World economic forum, 2019)

The council of foreign relation have indicated that when the world is fully governed by the democratic government, there would be spontaneously election year after year as the tenure of every succeeding government ends where by new election approach to be elected and every year 10 countries election would be taken place which could be watched by the world and by proportion $5.98 \%$ election would happen every year in a world. (Lindsay,2018). On the contrary, (Sadegh,2017) has described that every countries in a world has been driven by evolution of democracy and the election in a world is emerging time and again after every stipulate term of government tenure which become essential roles for every concern authority involving in election and particularly the politicians or an aspiring candidature either of national council or national assembly contestant has a significant roles in promoting them self where they could promote their image, Pledges, appearances, work knowledge and party views as a political marketing

The political marketing has a concrete thing to be described and it denotes various form of political communication that explicitly focused on making informed decision to electorates within the jurisdiction of electoral campaign. It involves the intrinsic approach whereby the politician or a candidate promote themselves and their pledges to electorates through profound communication targeted at gaining optimum support from the public. The concept or ideology of political marketing has been originated by Kotler through the mass debate of marketing in early 1970's however the execution and implementation in the reality was brought by Kelly in 1956 as a mandatory requirement not only for the politicians but as a wholesome education curriculum for the scholars in getting the real essence of political marketing
Political marketing is explicitly modern concept in this era of political science inherited from the marketing of product and services where it signifies the need of marketing tools, methods and techniques in political routine. It was also described as bridging the gap of political space through marketing and denoted as an outcome of marriage between the politician and the marketing. (Menon,2008). The concept of marketing for goods and services has been flourished into political marketing where it does not valid to only product and service marketing domain. Unlike the marketing for the goods and services, the political marketing could be feasible in real ground as it has parallel application and significance towards every election either be the local government or parliamentary election. The concept of marketing the product and services has been shifted to political marketing whereby every strategy of marketing has been executed in political marketing campaign to reach out the electorate or voters as a part of advocacy program in the election. (Jeff,2012)

As cited by the (Davidson and Binstock, 2011), about the political marketing concept and ideology, the strategy of marketing plays the crucial roles in election to communicate with every voters or electorate to give the platform of informed decision to the public in making precise and good choice of every representative. It has significant roles in reaching out their electorate to fetch better support from the public and without having proper political marketing plan, politician can't succeed in any election. It is not about the political image and personality to win the election as it involves holistic approach in making the successful trip throughout the journey of election. It means communication as a first priority where the politician should plan of creating value and benefits which is being desired by the community and come up with the solution to any conflicts and problem either of domestic or national issues that need immediate solution to the country, people and the society as a whole. It involves understanding the needs and demand of public, depicting the prospective electorates, develop the target group and know the tools to get the job done at optimum level. The success of an election is how the politician designed to communicate and promote themselves and it has been denoted as an explicit process of having artistic communication in electoral roles aimed at gaining the optimum vote and support. The political marketing has been driven by online campaigning through mass media advertisement, retail form of campaign and field operation campaign. The online marketing campaign consist of social media such as Facebook, Instagram, twitters, blogs, website, YouTube, live interview and email marketing. The field campaign has been the tiring job and expensive form of election campaign where it involves certain degree of cost and time that includes door to door campaign, common forum meeting and familiarization tours. There are several marketing ideas such as email marketing, develop website for a party, use social media, promote through distribution of flyers, develop catchy campaign logo, send any news related to political campaign to electorates and initiate an aggressive advertisement campaign 


\section{International Journal of Engineering Applied Sciences and Technology, 2021 \\ Vol. 6, Issue 2, ISSN No. 2455-2143, Pages 111-127 \\ Published Online June 2021 in IJEAST (http://www.ijeast.com)}

Through such ideas the distinct strategy could be generated in many reliable key components such as content marketing strategy, online promotion strategy, mobile marketing strategy, word or mouth (WOM) strategy and social media strategy. So, political marketing is evolving at greatest height and the success of election depends on profound marketing strategy through proper communication channel that serve to be value proposition for the candidate and the electorate. (Durmaz and Direkci, 2015)

\section{BACKGROUND}

Bhutan experience the journey of 101 years of monarchy system from 1907 till 2008 and it was shifted into constitutional democratic system in March 2008, which is destined as one of the youngest democratic country in a world. Since then, the parliamentary or the assembly is divided into two core distinct designation, "the upper house and the lower house". The national council is upper house which does not belong to any political party, and they are apolitical which comprise of Druk Gyalpo (the king), the national council and the national assembly. (Council foreign relation, 2008). The national council is denoted as upper house where it has 25 members as a representative of public. Out of which, 5 members so called "eminent members" are nominated by His majesty the king from the senior government official of royal civil services commission where no election are being placed. The rest 20 members are being elected by the public and each member represent their own district and that totaled to 25 members in national assembly. (National council of Bhutan,2019). There are two function of national council categorized as legislative function and review function. As a legislative function, they take in-charge of preparing the legislation, review, enact and endorse old and existing laws, pass and amend the laws or revoke the legislation channeled by the national assembly. As a review function, they act as a review house where they review the plan, policies, program and the performance of government which caters to review the resolution, issues or a problem of national interest being passed by national assembly. (Election guide,2019). The qualification and eligibility are mandatory where it is one of the screening processes to be observed by every aspiring national council candidate. The following entails some core requirements

$>$ The candidate must be Bhutanese citizen where he or she should hold citizen identity card as an evidence of validity.

$>$ The candidate should be the registered voter of his or her constituency

$>$ The age has great significance as the minimum age is 25 and maximum is 65 years at the time of filing a nomination
The aspiring candidature does not belong to any political party affiliation. (National council of Bhutan, 2019)

The elected candidate has five years term of service, and it is subjected to change after every five years and reelection would be held after every five years. There are basically two types of election. The primary round of election being held in a gewog or sub district and once the candidate is being nominated from gewog level, the candidate would go in final or general election in district level and who ever got elected from district level would serve as a member of national council which is representative of that district. (Election commission of Bhutan, 2019)

On this front, the author itself is designated as an aspiring candidature and intended to do the political marketing for the promotion of candidature where the researcher himself is a brand and product to promote in a market. This is being done as a preparatory task for the future election for the author where the target group ought to be the resident of people in his sub-district and district of ages between 18 till 24 as a youth and 25 to 45 as an adult excluding monks and abbot rulers in a country. The resident involves students, civil servants, private and corporate servant, arm force, businessman and general public (Farmers)

\section{OBJECTIVES}

The objective of a research is mandated to study the followings

- To evaluate the current political market and ascertain the eligible voters in district level

- To evaluate the values, needs and wants, desire and expectation of eligible voter

- To develop effective marketing strategy that fulfil the needs and wants of eligible voters

- To develop marketing brand and plan that serve as a guiding tool for candidature

\section{METHODOLOGY}

The research methodology for the plan has been derived according to the predetermined research questions and objectives in chapter - I. The objective pertaining to plan is to evaluate the current political market and ascertain the eligible voters, to evaluate the values, needs and wants, desire and expectation of eligible voters, to develop effective marketing strategy that fulfil the needs and wants of eligible voters and to develop marketing brand and plan that serve as a guiding tool for candidature. On this front, this research have adopted both qualitative and quantitative Methods. As a primary data collection, both qualitative data and quantitative are used. The primary data has been collected through the execution of google form survey where every data are captured, analyze, interpret and retrieve at any time. The survey money rules formula and the Solvent's formula are used in achieving the 


\section{International Journal of Engineering Applied Sciences and Technology, 2021 \\ Vol. 6, Issue 2, ISSN No. 2455-2143, Pages 111-127 \\ Published Online June 2021 in IJEAST (http://www.ijeast.com)}

reliability of research where it indicates the requirement of sample size and confidence level formula. The sample size as per the formula was 383 with population size of 100,000 in achieving $95 \%$ confidence level of research with 5\% margin error or alpha. The qualitative includes the focused group and TDI (Telephone in-depth interview) where there are 16 members for focused group discussion from sub-district electorates and 10 TDI respondents from village electorates. The finding of qualitative data are interpreted through recording and listing in tabular format where the discussion are informal and unstructured. The followings is the survey monkey rule and Solven's formula adopted in studying the requirement of sample size of this research

\section{a) The Survey monkey rule formula diagram}

\begin{tabular}{|c|c|c|c|c|c|c|c|c|c|}
\hline \multirow{4}{*}{$\begin{array}{l}\text { PPL } \\
\text { size }\end{array}$} & \multicolumn{6}{|c|}{ Confidence Level $=90 \%$ Confidence Level $=$} & \multicolumn{3}{|c|}{ Confidence level $=99 \%$} \\
\hline & & & & $95 \%$ & & & & & \\
\hline & \multicolumn{3}{|c|}{ Margin of error } & \multicolumn{3}{|c|}{ Margin of error } & \multicolumn{3}{|c|}{ Margin of error } \\
\hline & $5 \%$ & $2.5 \%$ & $1 \%$ & $5 \%$ & $2.5 \%$ & $1 \%$ & $5 \%$ & $2.5 \%$ & $1 \%$ \\
\hline 100 & 74 & 92 & 99 & 80 & 94 & 99 & 87 & 96 & 99 \\
\hline 500 & 176 & 342 & 466 & 217 & 377 & 475 & 285 & 421 & 485 \\
\hline 1000 & 213 & 519 & 871 & 278 & 606 & 906 & 399 & 727 & 943 \\
\hline 10000 & 262 & 972 & 4,021 & 370 & 1,332 & 4,899 & 622 & 2,098 & 6,239 \\
\hline 100000 & 269 & 1,065 & 6,301 & 383 & 1,513 & 8,762 & 659 & 2,585 & 14,227 \\
\hline 500000 & 269 & 1,074 & 6,635 & 384 & 1,532 & 9,423 & 663 & 2,640 & 16,055 \\
\hline 1000000 & 269 & 1,075 & 6,680 & 384 & 1,534 & 9,512 & 663 & 2,647 & 16,317 \\
\hline
\end{tabular}

a) The Solven's Formula

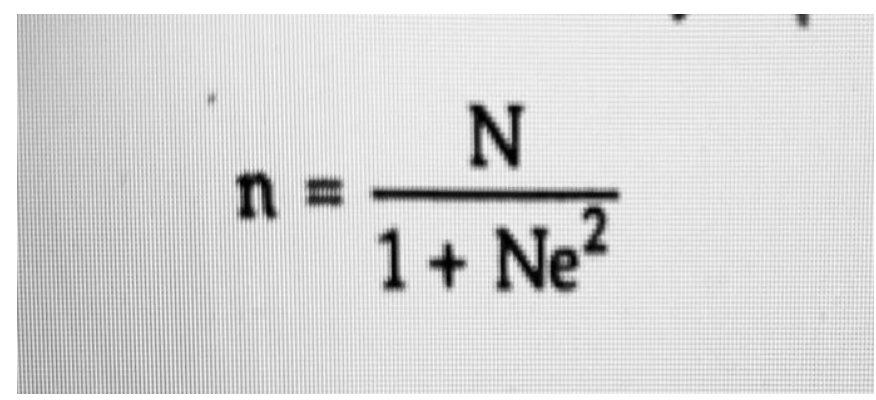

Sources: (Slovin's formula, 2019)

$\mathrm{N}=$ Population size

$\mathrm{e}=$ Margin error

$\mathrm{n}=$ Sample size

So, by deputing the formula as underneath, sample size of survey are as follows

$$
\begin{gathered}
100,000 /\left(1+100,000 * 0.05^{2}\right) \\
=398.406375
\end{gathered}
$$

It is 398.406375 and by round off, it is 399 sample size of this survey.

The sample size of population; 100,000

The sample size; 399

The confidence level; $95 \%$

The margin error: $0.05 \%$ or $5 \%$

So, asper the rule of thumb of survey monkey, if margin error is $10 \%$ or more with confidence level of $90 \%$, then it's not reliable. So, this survey ought to be feasible and accurate as per the calculation by implying the Solvin's formula and margin rate of $0.05 \%$ and confidence level of $95 \%$ with the sample size of 399 . However, the researcher got 400 respondents. The data was analyzed through computer assist system through the descriptive analysis in interpreting the results. To get better insight about the political market, the secondary data are used in generating the eligible voters in a country and district level. It includes content analysis, You-tube, company webpage, journals, newspaper, e-books and google scholar

\section{ANALYTICAL TOOLS}

Proceeding to analytical tools selection, there are broad range of analytical tools wherein all the tools are not applicable to marketing plan. Every tool is subject to change with different usage and their application that amusingly depend on the things that execute and implement them according to the specific purpose. The analytical tools are mandatory equipment where the tools itself is executed to analyze something that is required for marketing plan and interpret the findings and implement the outcome towards gainful impact to marketing efficiency, productivity, reliability and outcome (Vohra,2019). Thus, the marketing analytical tools for this marketing plan includes PESTLE, SWOT, STP, MOSCOW analysis and 5 why's analysis detailed in this section

The marketing mix 7p's and the blooms taxonomy has been also used as a part of accessing the plan and develop the strategy through 7p's analysis which is a not analytical tool but tools for implementation of strategy and blooms taxonomy is level of thinking assessment of candidate being used in this plan; The concept of PESTEL analysis has been derived from the four-capital letter of PEST which was created and formulated by Harvard professor Francis Aguilar originally classified in his book as ETPS about a decade ago in year 1967

$$
\mathrm{n}=\mathrm{N} /\left(1+\mathrm{Ne}^{2}\right)
$$




\section{International Journal of Engineering Applied Sciences and Technology, 2021 Vol. 6, Issue 2, ISSN No. 2455-2143, Pages 111-127 \\ Published Online June 2021 in IJEAST (http://www.ijeast.com)}

Later the name flourished into PESTEL analysis, and it is resemblance to the ideology of SWOT analysis however SWOT is limited to certain business factor analysis whereas PESTEL has a broad factor to be determined applicable to any sort of business entity. (Mindtools,2018). PESTEL analysis has a broad factor to be determined as it has wide external analysis of political environment in every lens and angles from different dimension

Through which it gives greater significance and impact to candidate as a politician in understanding about the macro environment that could possibly affect the election or promotion of political marketing of candidate. The underneath comprises of few lines of its significance towards political journey of election in succeeding the plan; PESTEL analysis would enable to identify the external threats and opportunities of a candidate as a politician there by it contribute to gainful recognition of threats where the candidate needs to be cautious of and visualization of opportunity to be grasp during the course of election. So, this analysis would enable threats and opportunity as a key significant measure to be sense by the candidate in combating the challenges and take the opportunity to proceed with further enhancement and growth in support towards attainment of perpetual existence of political journey. So, in this marketing it could enable the author to sense the external threats towards promotion of political candidate as a brand and product in a market. It would be roadmap to direct and guide in changing the political environment with the change in time and technology

This realization would sense what the candidate is doing, and it leads to work for change to keep update with present requirement. Through this analysis, it enable the candidate in keeping update with the political market and the environment. It also serves as a protective guide for the candidate before taking part in election that resemble to fail for any reason. It leads by beyond control of candidate as a politician. So, those alarming fact would give better insight for the candidate to be cautious of their capacity and potentials to work and adapt what is demanded in politician

PESTEL analysis would enable the candidate to have greater exposure and construct the objective view pertaining to new environment challenges. (Amable,2018). The 5 - why analytical tools were being developed by one of the profound journalists who was inventor and founder of Toyota industry where it was originated in 1930's and it became renown and most popular analysis for any sort of industry and business especially the start-up business and marketing plan. The Toyota company still execute this tool as a part of analyzing the cause and effects of problem in both long and short run and how business actually contravene the issues in resolving the problem at greatest height. (Toyoda, 1970) The "5 - why" is an analysis of identifying the root cause of problem or needs. It is holistic approach towards understanding the root cause of any problem and through which it helps in determining the problem and why it cause it

So, the analysis is applicable to political marketing planning in identifying why could not succeed in election, what are drawback and what cause it to failure of victory. The concept is not limited to certain degree of application to particular industry or a firm as it has in-depth analysis to understand the root cause and start combating, controlling and avoiding the risk or mitigate the risk. It enables every stake holders, entrepreneurs and business entity to identify the loopholes of a problem and treat at earliest before everything ruin into major collapsed. (Mindtool,2018)

The MOSCOW analysis is one of the analytical tools and prioritization method or technique which is being executed in marketing and business analysis in management level that caters to provide guide on what is need and what is want in a business. It is applicable to political marketing plan as it prioritize the things that is required by a candidate in promoting in a market. As a politician there has to prioritize the things based on necessities in having effective political journey, which is why the MOSCOW analysis came into existence. It will also direct what is utilitarian needs and what is hedonic need. So, through this analysis, it would prioritize what the politician must intend to have and should have as a mandatory requirement otherwise it would hamper in operational journey of election. Thus, must have and should have is ought to be utilitarian needs whereas could have and would have is kind of hedonic need and it would be just wish and pleasure experiment where its existence does not impact much to the political activities. Through this analysis, it could sense what the politician dedicated to serve and promote the things that the candidate needs to deliver to electorates in a market. What is must requirement in a candidate and electorates? what should have by the candidate and what should electorates expect from politician. So, this analysis is designed to set priority of needs or wants to serve to electorates or public in real ground based on the necessity and need recognition. (Haughey, 2019)

The SWOT analysis is applicable for any business plan apart from political marketing plan and it is applicable to both personal and professional life. It is being designed to help the candidate identify their strength and weakness and try to take the advantage of strength and improve the weakness to beat the competitors in a market. It could also help the political candidate in enabling the opportunity and threats and through which it helps the candidate to strategically plan to distinguish from competitor. So, that candidate could successfully compete and survive in the market where it minimizes the risk of failure in election journey. (Suradech, 2019)

The neither analytical tools called STP analysis is one of the most prominent and reliable tools applicable to any sort of 


\section{International Journal of Engineering Applied Sciences and Technology, 2021 Vol. 6, Issue 2, ISSN No. 2455-2143, Pages 111-127 \\ Published Online June 2021 in IJEAST (http://www.ijeast.com)}

business entity and same logic is used in political marketing plan. Through this analysis, the candidate could rightly target the potential electorates and position the candidate product offering in the mind of target group at right place at a right time. So, segmentation is core ethic before targeting and positioning, it involves various mode of segmentation through certain variables or factors such as demographic, behavioral, psychographic and geographic segmentation and accordingly target the electorates and position the candidate product offering. The STP analysis is holistic approach towards gaining the right and potential supporters through which it enables the candidate to strategically plan to adopt right strategy towards the election in achieving the gainful performance and goal of candidate. (Kokemuller, 2018)

\section{ANALYSIS AND STRATEGY}

The afore mentioned analytical tools depicted in accordance with the application in this research would be analyzed and interpreted in this section in understanding how it impact towards the plan. The PESTEL is the macro environment analysis focusing on external environment that could possibility cause an impact towards political marketing if not examined in plan. (Economic profile, 2019)

Table 1; The PESTEL analysis

\begin{tabular}{|c|c|c|}
\hline Political & Economic & Social \\
\hline $\begin{array}{l}\text { Policy of } \\
\text { government } \\
\text { Political stability } \\
\text { Election rules \& } \\
\text { regulation } \\
\text { Certification \& } \\
\text { accreditation rules }\end{array}$ & $\begin{array}{l}\text { Economic growth \& } \\
\text { stability } \\
\text { Foreign exchange } \\
\text { rate } \\
\text { Currency exchange } \\
\text { rate } \\
\text { Financial position of } \\
\text { candidate }\end{array}$ & $\begin{array}{l}\text { lifestyle } \\
\text { Culture barrier } \\
\text { population growth } \\
\text { rate } \\
\text { Age distribution } \\
\text { The career attitude }\end{array}$ \\
\hline Technological & Environmental & Legal \\
\hline $\begin{array}{l}\text { Research \& } \\
\text { innovation } \\
\text { Technological } \\
\text { knowledge } \\
\text { Technological } \\
\text { change } \\
\text { Technological } \\
\text { adaption } \\
\text { Technological } \\
\text { awareness }\end{array}$ & $\begin{array}{l}\text { Climatic change } \\
\text { Weather Condition } \\
\text { Environmental } \\
\text { polices } \\
\text { Ecological pressure } \\
\text { Political impact to } \\
\text { environment }\end{array}$ & $\begin{array}{l}\text { Election law } \\
\text { Documentary } \\
\text { process law } \\
\text { Electoral law }\end{array}$ \\
\hline
\end{tabular}

Sources; (Author,2019)

PESTEL is the external environment of a business that has direct or indirect impact towards business and all the factors are thoroughly considered. The candidate as a politician should have thorough intervention with the political factors and undergo the policy of government that favor the candidate's credibility to come up with the political plan in promotion of the product and the brand in a market. Subsequently, the political stability, election rules \& regulation, certification \& accreditation rules has impact towards promotion of candidate as a product. However, through this analysis, the author as a candidate have to realize the political stability as a core concern as a democratic country and it may impact to promotion of political marketing. (Economic profile, 2019). According to (Adam Smith, n.d), "an economic is science of wealth" and this plan has profound economic study on economic growth \& stability of Candidate, foreign exchange rate or currency exchange rate that hampers in meeting the fund and financial position of candidate

The economic here is referred as the initial investment fund for political marketing. It refers to the economic stability to finance for marketing through different channel. So, to promote political marketing, economic plays a vital role otherwise it can't bring success in electoral role. Therefore, the funding fund of 10,000 USD has been managed to run the electoral campaign and promotion activities and the state funding of 70,000 Bhat would be the supplement budget to run the election that could have great impact towards successful operation of plan. The details of budget allocation would be available in implementation, evaluation and control plan chapter vide page 135 . The social aspect is very important for political marketing plan. It means how the customer would perceive towards the product and what are their needs and wants in a market. So, political marketing should prove their product to be utilitarian rather than hedonic needs

The product for political marketing would be candidate itself and candidate should identify the social needs of a public, know the prospective electorates, target the certain segment and implement the tools to capture those segments. Thus, the candidate profile and the pledges has rightly matched with social requirement of public. For an instance, the candidate pledges are based on public needs and wants and try to offer what they need in a market. It includes the study of lifestyle, culture barrier, population growth rate, age distribution and career attitude of external environment that is general public as an electorate

The technology is very important for political marketing. With the change in time and technology it could have good impact to political campaign. For an instance, through computer assist, we can do online marketing, take advantage of social media, content marketing, website promotion, email, text messaging and YouTube platform. So, all this infrastructure is driven by the technological that give great impact towards political marketing and those platforms are rightly executed in promotion of candidate as a product or brand in a market. The Research \& innovation, technological knowledge, technological change, technological adaption and 


\section{International Journal of Engineering Applied Sciences and Technology, 2021 Vol. 6, Issue 2, ISSN No. 2455-2143, Pages 111-127 \\ Published Online June 2021 in IJEAST (http://www.ijeast.com)}

technological awareness are core studies of the plan and it proved to be feasible

Every business irrespective of any nature ought to have some environmental cause and effect however, since the marketing plan is just to analyze the ideas, methods, tools and strategy of political marketing and it won't have impact on the natural environment like factory business. It has no fear of pollution to be detected that could harm to environment as it is all about political marketing that entails to promote the candidate through different methods of promotional tools for election campaign. The factor such as climatic change weather condition, environmental policies, ecological pressure has no impact to environment. Legal here is referred as rule and regulation and formalities that restrict towards formulation of developing political marketing plan

There is no legal disruption towards development of political marketing plan as it is franchise for every aspiring candidate to explore and research on political marketing plan that does not contravene to any article of law of election commission of Bhutan. The legal consideration includes election law, documentary process law and electoral law

The detail of candidate SWOT is being analyzed in chapter II of this plan. However, prior SWOT is just figure of SWOT and its application in the plan are emphasized. Here it is being focused where internal strength and weakness of a candidate would be discussed in-order to make comparison and contrast with the competitor analysis and recognize the area of opportunity for a candidate

\section{Table 2; Candidate SWOT analysis}

\begin{tabular}{|c|c|}
\hline Strength & Weakness \\
\hline $\begin{array}{l}\text { Good communicator } \\
\text { Take prompt decision } \\
\text { Face in media } \\
\text { Management of time } \\
\text { Good interpersonal skills }\end{array}$ & $\begin{array}{l}\text { Lack of campaign budget or fund } \\
\text { Man-power to support the } \\
\text { campaign } \\
\text { Poor in research of political } \\
\text { affairs } \\
\text { Poor in aggressive campaign } \\
\text { Poor in using campaign tools }\end{array}$ \\
\hline Opportunity & Threats \\
\hline $\begin{array}{l}\text { Take advantage of social } \\
\text { media marketing campaign } \\
\text { such as Facebook, We-chat, } \\
\text { WhatsApp etc. } \\
\text { Take part in politician from } \\
\text { apolitical } \\
\text { Gain rightful tools for } \\
\text { campaign } \\
\text { Gain right strategies }\end{array}$ & $\begin{array}{l}\text { Competitor experience \& } \\
\text { background } \\
\text { Word of mouth influence } \\
\text { Bias in voting } \\
\text { Time \& cost }\end{array}$ \\
\hline
\end{tabular}

Sources; (Author,2019)

\section{Strength}

\section{○ Good communicator}

Through the working experience in various occupation by the candidate has given an advantage as a strength to communicate well. The roles of both formal and non-formal teacher and administrative assistant dealing with various people has given a plat form to develop a communication skill to have good communication skills. The communication skill is one of the intrinsic requirements as a candidate in representing the locality

\section{- Take prompt decision}

The decisional role is one of the key qualities need to be possess by the leaders. The decisional roles involve taking the decision on all important matters that need to prioritize and sort out based on the urgency. The candidate has a skill of taking a prompt decision that is needed as and when situation demand

\section{- Face in media}

Through the past experience as an aspiring candidature, the candidate has a strength to face the media in creating awareness and advocacy about the candidate platform. The media interview such as one on one interview live conducted by the national television, online broadcast of candidate wills and advocacy programs is one of the mandatory requirements as a part of familiarization

So, the candidate has strength to face those platforms

\section{○ Management of time}

The candidate before election and after election has lot of areas to focus on. It involves managing the time for campaign, familiarization and dealing with the media and concern authority for designed task to be perform as a part of requirement by the candidate. So, the time management plays crucial roles in electoral role where candidate has good strength of time management

\section{○ Good at interpersonal roles}

The interpersonal role and informational roles are key ingredient of every leadership. It means the figure head roles in representing the public where the chain of relationship has to maintain in every sphere of election. It involves the relation with public as a most key requirement followed by every person who involves in electoral role. (Mintzberg, 2019). So, the candidate has an interpersonal role as a strength

\section{Weakness}

\section{○ Lack of budget or fund}

As a national council candidate, the coverage of campaign place is 11 sub-district or Gewog which is vast areas to be 


\section{International Journal of Engineering Applied Sciences and Technology, 2021 \\ Vol. 6, Issue 2, ISSN No. 2455-2143, Pages 111-127 \\ Published Online June 2021 in IJEAST (http://www.ijeast.com)}

covered within short span of time and meeting with every household under each sub-district people has time and cost implication. Therefore, the budget is obvious weakness as a candidate have to meet the required capital such as working capital expense during the electoral campaign. There is no rules and platform for raising a public fund for campaign in national council election which impact a candidate to meet the required expenses during the period of election nor no sponsor does the funding assistant for the candidature. However, the state funding of Bhutanese currency Ngultrum 150,000/- (One hundred fifty thousand) equivalent to $70,000 /-$ (Seventy thousand) Bhat would be granted by the government as a campaign fund for the election

The campaign fund is sanctioned or liable in the ground, if the aspiring candidate is being nominated by the public in primary round of election. If he or she is not nominated in the primary round election, the afore mention fund is not eligible or granted by the concern authority. Therefore, till the primary round election, there could be various platform for the promotion of campaign such as familiarization tour which is door to door campaign and live broadcast as a part of familiarization in air and those platforms is utilitarian needs for the candidature. However, without adequate budget or expense would hamper in availing those platforms in real ground

\section{○ Man, power to support the campaign}

The place in Bhutan is diverse and every sub-district have to travel a mile to meet with the electorate or voters which is daunting task and journey as it is hill area where it requires manpower to support the candidate in creating the awareness and advocacy about the candidate as a product. However, getting a manpower to support in electoral roles became difficult and with single man to deliver and take in-charge of every activities pertaining to campaign necessities becomes inefficient. Asper the election commission of Bhutan (ECB) guidelines, a candidate could appoint polling representative but he or she is authorized to just count the voters against the candidate when public voted. He acts as a middleman to monitor and receive the count of votes received in pool day as the candidate can't be accessible to all the polling station. So, the candidate could appoint only one candidate representative to do the campaign on behalf of the candidate in diverse place and still the manpower would be inadequate to support the election

The candidate could appoint any length of representative but asper the provision, only one candidate representative is authorized and in real round it is not adequate to assist the electoral programs

\section{- Poor in political research affairs}

One of the probable weakness of a candidate is lack of research on political requirement. The probability of winning is driven by the advance research before handling the situation in real ground. However, the candidate being new to appear in election does not have any research and that have hampered in capturing what to serve and how to serve the requirement of public

\section{- Poor in aggressive campaign}

The aggressive campaign is an attempt to win from the competitors. As part of understanding what the competitors are doing in capturing the market. It involves the strategies, tools, methods, programs and the tactic that is being executed in influencing the mind of public by the competitor and try to grasp the area of performing better than the competitor

\section{- Poor in execution of campaign tools}

The campaign tool is one of the necessities of candidate. It involves the strategies, tactics, and methods executing the campaign or familiarization. The execution of inappropriate tools leads to inefficient performance of a result in having a victory

\section{Opportunity}

○ Take advantage of social media marketing campaign such as Facebook, We-chat, WhatsApp etc.

After having research on competitive analysis of candidate through contrast of strength and weakness of competitors, there is an opportunity to take an advantage of social media marketing such as Facebook, We-chat, WhatsApp which the candidate has never take those platforms in the past election

\section{- Take part in politician from apolitical}

As a candidate there is always a point where shifting could be possible in election. The parliamentary election has two types of election. The national council and national assembly election. So, national council is apolitical where the candidate could shift from apolitical to political contestant as an opportunity

\section{- Gain rightful campaign tools and strategies}

After having the comparative analysis, the candidate has an opportunity to use the aggressive political marketing tools such as word of mouth strategy, public relation, online marketing through dedicated webpage as the candidate have never used those platforms in the past

\section{Threats}

The threat is uncontrollable factors which is beyond the control of candidate as a contestant. The threats related to candidate election are as detailed as follows

\section{Competitor's experience and background}

The competitor experience and background has huge impact on election. So, the candidate having qualified background 


\section{International Journal of Engineering Applied Sciences and Technology, 2021 \\ Vol. 6, Issue 2, ISSN No. 2455-2143, Pages 111-127 \\ Published Online June 2021 in IJEAST (http://www.ijeast.com)}

and experience gives a threat in public choice as public select the candidate based on experience in some extent

\section{Word of mouth influence}

The word of mouth is one of the influences in choosing a candidate by the electorates and candidate has no control over those factors. The voting would be ominously driven by the word of mouth influence as one of the threats to candidate

\section{Time \& Cost}

The time and cost in election is always manageable but can't control by the candidate. The time is always limited to have the campaign as it is controlled by the concern authority and within stipulated time frame the candidate has to do the campaign or familiarization which is always a threat for a candidate

MOSCOW analysis is one of the reliable tools to give better insight on how candidate could appropriately adopt which is required and what is not required in the course of political marketing. It is simple to assume that everyone could decide what is required and what is not required but in real ground it is complex things to do

That's why this MOSCOW analysis was one of the analysis which is being invented and develop by Dai Clegg in creating value to the business and the customers and it is used in political marketing plan as-well. It involves the key focus on what candidate could deliver as a value and how candidate achieve its value proposition through categorizing the things into level of importance. (Clegg, 2019). So, this plan uses this tool as one of the analysis on how researcher as a candidate could focus on what to have and what not to have in course of election or marketing

\section{Diagram 2; MOSCOW analysis}

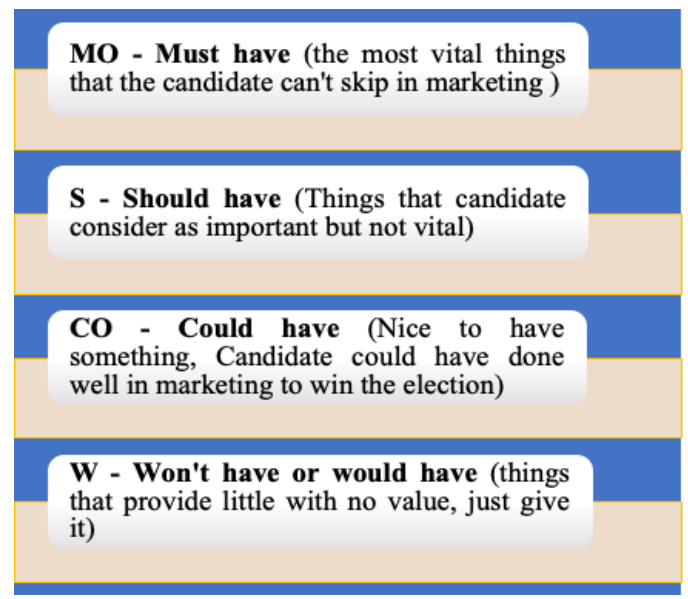

Sources; (Author,2019)

\section{MO (must have)}

Most have is mandatory where there are no substitution and without having the most needed, the end result can't be achieved. (Riddix,2019). The candidate must have eligibility to contest which means no legal and crime record, qualification and ages requirement being meet asper the electoral law. They must need good public relationship (PR) with everyone

The candidate must have good strategies for political campaign and good pledges or manifesto to create the value and influence the public for voting which the candidate possess all this key requirements

\section{S (Should have)}

Should have are additional requirement which supposed to be top priority needs and it starts with the capital, operation management, manpower, resources, skills, expertise, experience and the technology otherwise just plan could be not reliable in real ground to have a success in business as it is ecosystem linkage and collaborate task to achieve the business goals. (Tool's hero,2019). Thus, candidate should have financially sound for campaign, manpower to support the election campaign, resources and the technology to support the daily transaction of election activities and after doing research on it, the candidate has equip with all those necessities towards success of 2023 election.

\section{CO (Could have)}

Could have has no adverse effect on the performance of business or end result where it is not utilitarian needs, and it is not that mandatory as must have and should have necessities. Even it does not have in business, it may not necessarily require but it is good to have something as a supplement measures to combat the problems. So, candidate could have more transport for election duties and more manpower to help and build PR with public.

\section{WO (Won't have or would have)}

Would have is futuristic and it would be just won't have as a final binding towards what we aspire to wish for. It would be just wish and business should have not much attention towards would have, as it may hamper the business productivity as we focus beyond our capacity and potential and it is just wish when we have something in front and aspire to have more illicit things which is not required. The candidate would not focus more on that part and do what is required and necessary. The 5 why analysis is a tool that is used in the plan to understand the root cause of failure of election in the past. It depicts the causes of problem and probable solution to be adopted.

The "five why" analysis tool is explicitly designed for problem solving either large or small scale of issues. It is holistic approach towards understanding the issues or a problem in any sort of business either of large or small firm or 


\section{International Journal of Engineering Applied Sciences and Technology, 2021 \\ Vol. 6, Issue 2, ISSN No. 2455-2143, Pages 111-127 \\ Published Online June 2021 in IJEAST (http://www.ijeast.com)}

even in every departmental problem, that 5 whys questions could really transform the root cause and ultimately, it would analyze the finding or the solution through several brainstorming on the issues. Through which the findings even suggest and recommend addressing the problem. So, this analysis could determine three key factors such as what is problem with the politician, what cause that problem and what solution could be arrived through understanding the loopholes or root causes through determining 5 whys key aspect. (Pet therapy, n.d.)

\section{Diagram 4; 5 why application}

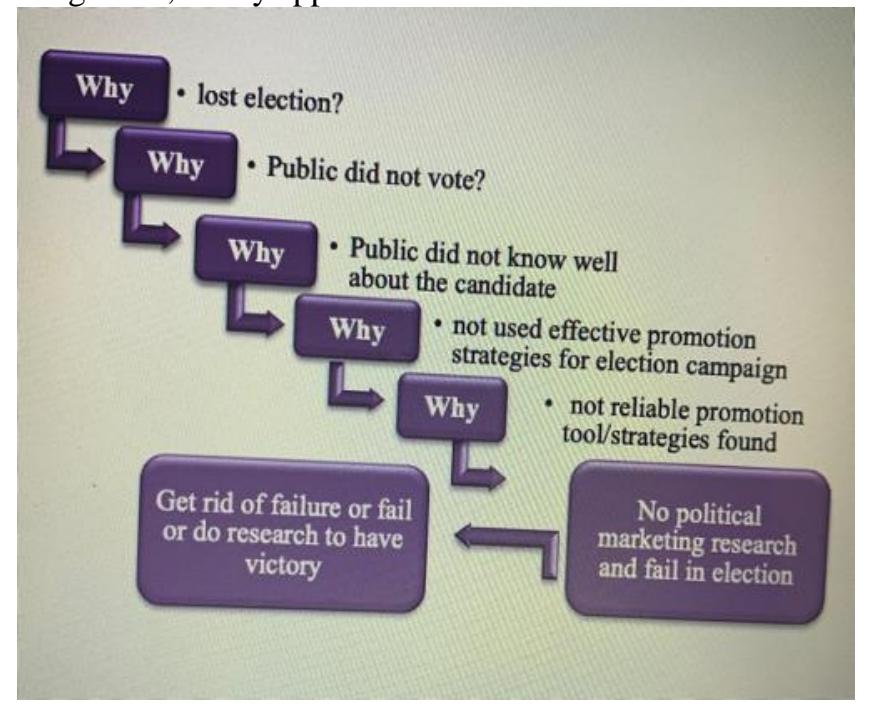

Sources; (Toyoda,1970)

Why lost the election?

Because public did not vote

Why did public not vote?

Public did not know well about the candidate

Why did public not know well about the candidate?

A candidate has not used effective promotion strategies for election campaign

Why have candidate not used effective promotion strategies for election campaign?

A candidate could not find reliable promotion tool/strategies

Why could candidate not find reliable promotion tool/strategies?

No political marketing research and fail in election

\section{Solution}

Get rid of failure or fail or do research to have victory

Through this analysis, the author as a candidate has understood the areas of requirement for the political marketing plan to foster the change and have better productivity and efficiency in next 2023 election. The 5 why analysis is being used by author to rightly figure out causes of failure in 2018 election that alarms of author to be cautious in doing research to gain better credibility result in future election. So, through this analysis, it was found that there was no political marketing research being done by a candidate that leads to fail in election because the author as a candidate has not known what is actually required by a public and did not come up with the pledges that could actually meet what they want as a utilitarian needs. Therefore, the candidate plan to do research on political marketing plan in- order to have victory in 2023 election

\section{The STP (Segmenting, targeting and positioning)}

The segmenting is to divide or categorize the public into different nature and form in deriving its unique choice and preference to have effective target market to deliver the market requirement. It involve demographic, geographic, behavior and psychographic segmentation. (Thompson, 2019) The political market can be broadly divided into four core segments. Demographic, Geographic, Behavioral and Psychographic

\section{The STP (Segmenting, targeting and positioning)}

The segmenting is to divide or categorize the public into different nature and form in deriving its unique choice and preference to have effective target market to deliver the market requirement. It involve demographic, geographic, behavior and psychographic segmentation. (Thompson, 2019). The political market can be broadly divided into four core segments. Demographic, Geographic, Behavioral and Psychographic

\section{Demographic segmentation}

This political marketing plan has demographic segmentation on demographic factors such as age, gender, occupation etc

\section{Gender}

According to constitution of Bhutan, there is no gender discriminatory in voting and every citizen of a country has equal civil and political rights. (Gyeltshen,2019). Consequently, the recent Chukha Dzongkhag administration, 2019, presented that there are 36,446 female and 47,757 male resident in total in a district. The total population in a district is 84,203 both male and female. The survey result indicated that there are male of $46.2 \%$ and female of $53.8 \%$. So, both male and female are focusing under gender category 


\title{
International Journal of Engineering Applied Sciences and Technology, 2021 \\ Vol. 6, Issue 2, ISSN No. 2455-2143, Pages 111-127 \\ Published Online June 2021 in IJEAST (http://www.ijeast.com)
}

\author{
Q1. Gender \\ 405 responses
}

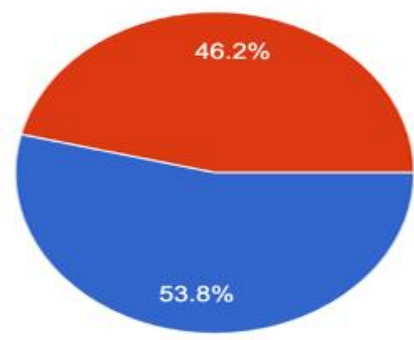

Female
Male

Figure 1; Gender distribution of market

Sources; (Author,2019)

Ages

Asper the election commission of Bhutan, 2018, the mandates of minimum age requirement for the voting by the resident should hold a citizenship identity card with ages of 18 and above and there is no old age bar for voting. Which means the ages above 65 are not required to renew or make new identity card but they can vote for the election. (Election commission of Bhutan, 2018). According to the index mundi Bhutan age structure, 2018, the ages between 0-17 years (Children) are of 25.8\% with 99,977 male and 95,652 female, ages between 18-24 (early working age/youths) are of 18.81\% with male 72,634 and female 70,018, ages between $25-45$ (prime working age/adult) are of $43.07 \%$ with male 173,310 and female 153,314, ages between 45 - 64 (mature working adults) above 65 (elderly, old age) with $6.29 \%$ with male 24,874 and female 22,821 respectively.

\section{Q2. Ages \\ 401 responses}

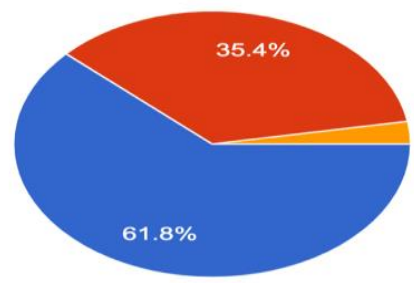

18 to 24

25 to 45

45 and above

Figure 2; Age distribution of market

Sources; (Author,2019)

Asper the survey result, the ages between 18-24 are youth with $61.8 \%$ respondents, 24 to 45 as an adults with $35.4 \%$ and 45 and above $2.8 \%$. Therefore, the age group focus are 18 years and above who is eligible voters with the mandates of election commission of Bhutan

\section{Occupation}

Asper the agriculture statistic, 2014, it stated that there are 76,792 farmers occupation in Chukha district. Accordingly asper the chukha dzongkhag administration, 2019, there are 16,285 students in 2015, 15,666 in 2016 and 15,476 in 2017. Consequently civil service statistic 2017 indicated that there are 2027 civil servant in Chukha followed by 8000 arm force and other category is just 7411. The survey result indicated that civil servant are of $21.8 \%$, students of $46.5 \%$, farmers of $7.2 \%$, others category of $23.3 \%$ and arm force of $1.2 \%$. The candidate will take all group of population as a segment; 


\section{International Journal of Engineering Applied Sciences and Technology, 2021 \\ Vol. 6, Issue 2, ISSN No. 2455-2143, Pages 111-127 \\ Published Online June 2021 in IJEAST (http://www.ijeast.com)}

\section{Q3. Occupation}

404 responses
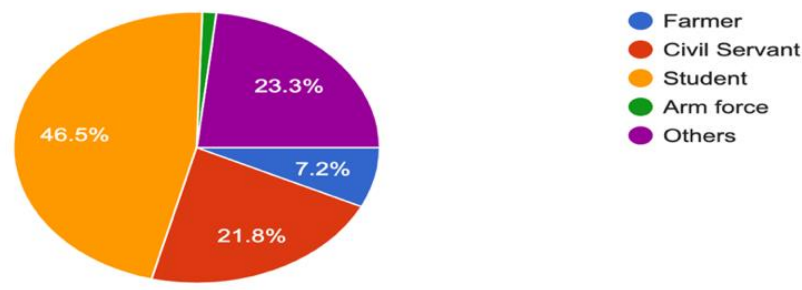

\section{Figure 3; Occupation distribution of respondents}

Sources; (Author,2019)

\section{A. Geographic Segmentation}

Geographic segmentation for a candidate is to segment the electorates groups based on the geographical boundaries such as village, sub-district and district. As a rule of thumb for segmentation, the core focus could be given to a place with highest population. However, the candidate focus on all three geographical location. This is because asper the election commission of Bhutan 2018, the election depot of parliamentary election would be in sub-district and the district which is destined as primary round and secondary round/final round. In primary round, it require the support of village eligible voters and sub-district eligible voters which is also called it as gewog center and those are the location that the candidate can't skip at any cost. In secondary/final round, the candidate need a support of all three location. They are village, sub-district and district. (Election commission of Bhutan, 2018). Therefore by considering the depot recognized by the election commission of Bhutan, the geographic segmentation are of village eligible voters, sub-district electorates and district eligible voters. Asper the national statistical bureau, 2019, afore mention in district eligible voter data, there are 18,268 eligible voter total male and female in year 2008, 19,586 in 2011, 21,317 in 2013 and 22,945 in 2018. So, this is a total eligible voters in district level which consist of village, sub-district and district eligible voters that belong to geographic in district. The following geographic location would be focus by the candidate

Diagram 16 The total sub-district location identified by election commission of Bhutan

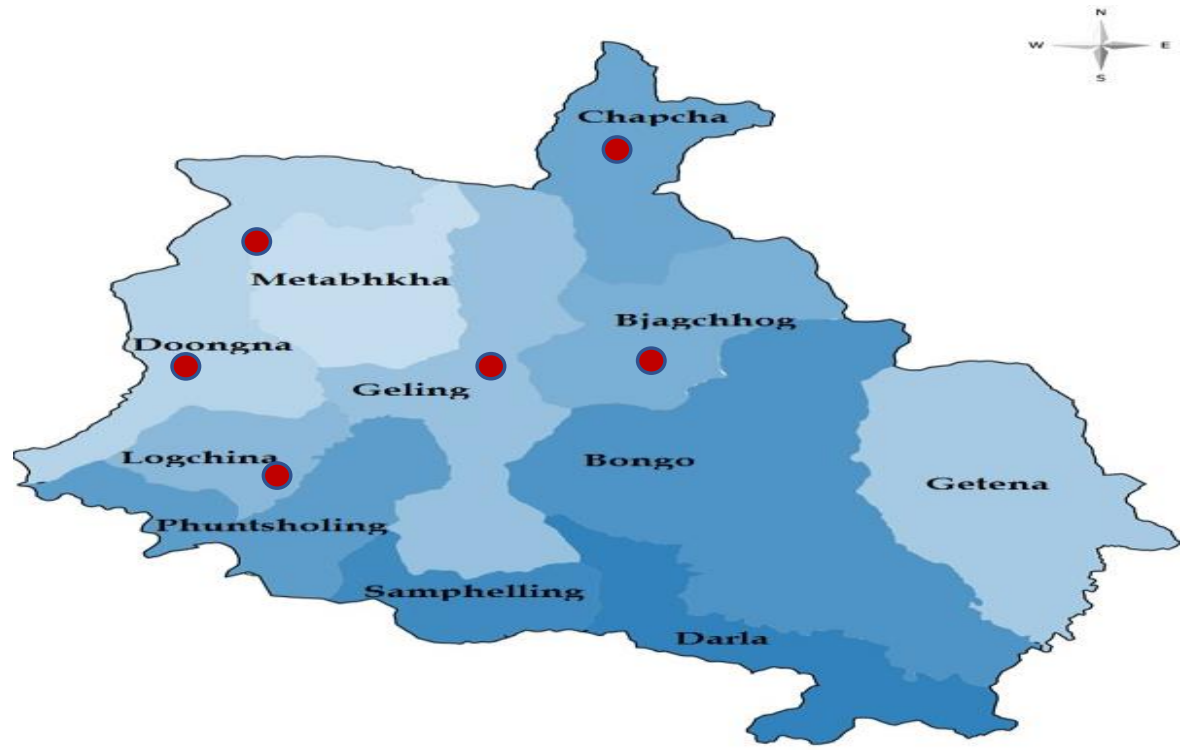

Sources; (Election Commission of Bhutan, 2013)

\section{B. Psychographic Segmentation}

Psychographic segmentation divides the mass market into different groups based on the values and perceptions of the electorates. It involves division on electorates groups based on their values, thinking, opinions, concerns etc. For the candidate, this includes sharing 


\section{International Journal of Engineering Applied Sciences and Technology, 2021 \\ Vol. 6, Issue 2, ISSN No. 2455-2143, Pages 111-127 \\ Published Online June 2021 in IJEAST (http://www.ijeast.com)}

of their problems and their needs and wants. So that the candidate could know their psychographic needs and their problem towards candidate to be resolved through electoral evolution

\section{Q4. Please select the voters needs and wants 404 responses}

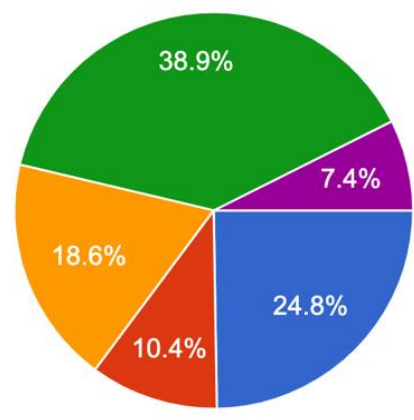

Infrastructure development such as motor road, electricity, transport services

Telecommunication such as internet

Education such as monastic education, modern education and traditional education

Fair \& justice in law and policy

Others

Figure 4; Voters needs and wants from respondents Sources; (Author,2019)

The diagram represents the psychographic segmentation towards voters needs and wants. The green portion denotes arm force where $38.9 \%$ require fair and justice in law and election. Red portion is a civil servant and $10.4 \%$ of respondents require telecommunication such as internet. The yellow portion denotes students and $18.6 \%$ requires education such as modern, monastic and traditional education. The blue represents the farmer and $24.8 \%$ of respondents needs infrastructure such as motor road, electricity and transport services. The purple portion is of $7.4 \%$ which has needs of other categories; so, author has core focus on needs of fair and justice in law and policy of $38.9 \%$ respondents, education such as modern, monastic and traditional education of $18.6 \%$ and infrastructure facilities of $24.8 \%$

\section{Q5. Select the severe problem for the voters that need to be resolved through political evolution \\ 403 responses}
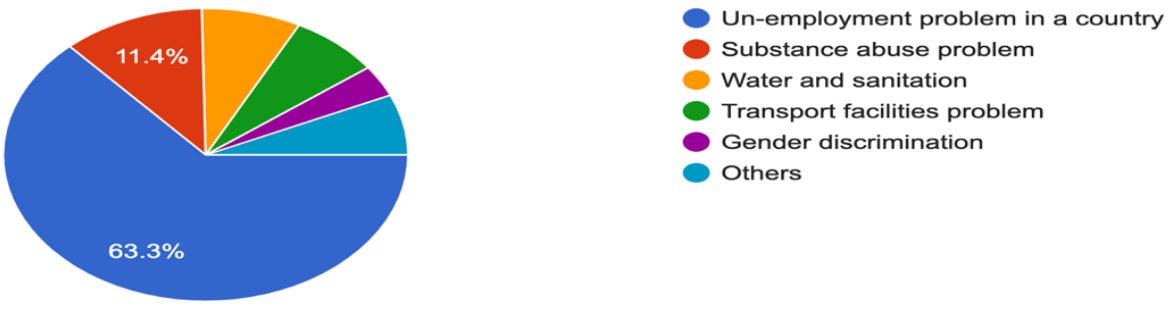

Figure 5; Voters psychographic towards their problems

Sources; (Author,2019)

Asper the psychographic segmentation of voters towards their problem, the farmers of $63.3 \%$ has highest concern on problem of unemployment in a country, $11.4 \%$ of civil servant has a concern on substance abuse problem. Subsequently, $7.9 \%$ of students has a water and sanitation problem, $7.2 \%$ of arm force has a transport facilities problem, $3.5 \%$ of others category of respondents has gender discrimination problem and $6.7 \%$ has problem as others category of problem. The author as a candidate has focus on unemployment problem of $63.3 \%$ and $11.4 \%$ of substance abuse problem.

\section{Behavioral Segmentation}

Behavioral segmentation is the division of the market into groups based on the behavior of electorates regarding the candidate as a product and brand and the benefit that they intend to have when they elect their representative; As per the survey research in focused group with the local leader, it shows that in order to change their behavior to vote, they need to know certain benefits that the candidate could provide and the effective communication channel that could adopt to communicate them and meet them to share 


\section{International Journal of Engineering Applied Sciences and Technology, 2021 \\ Vol. 6, Issue 2, ISSN No. 2455-2143, Pages 111-127 \\ Published Online June 2021 in IJEAST (http://www.ijeast.com)}

concerns and resolve issues. Therefore, a candidate segment based on the benefit sought and their behavior towards choice of effective communication channel

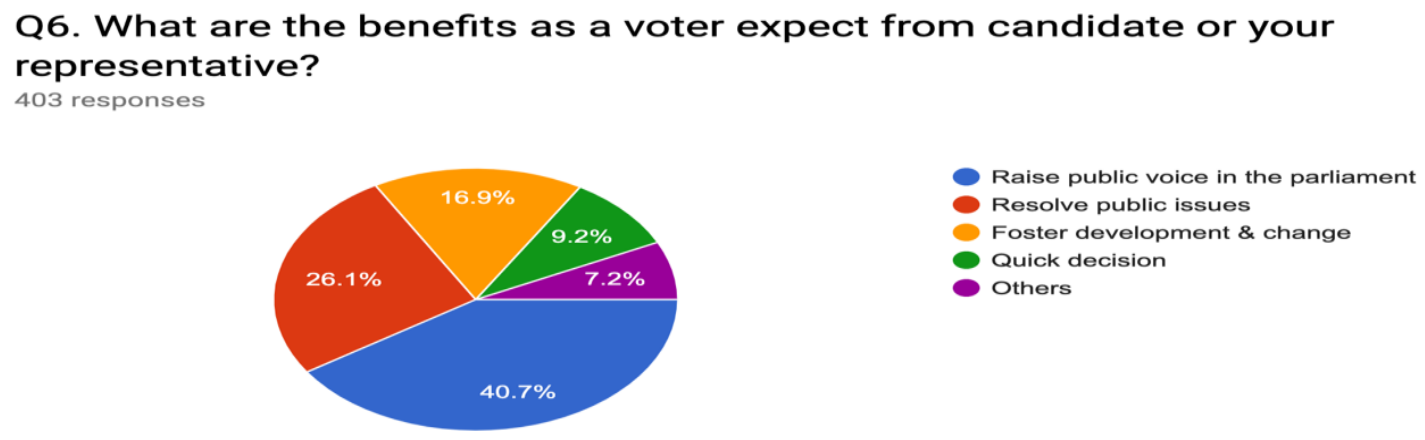

Figure 6; Voters benefits towards their problems Sources; (Author,2019)

Through the survey result, out of 403 respondents, $26.1 \%$ expect benefit of resolving public issues, $40.7 \%$ expect to have raise public views by the candidate in parliament, $16.9 \%$ respondent expect the benefit to foster development and change, $9.2 \%$ respondents expect the benefit of quick decision. The author choose to focus on highest respondent results
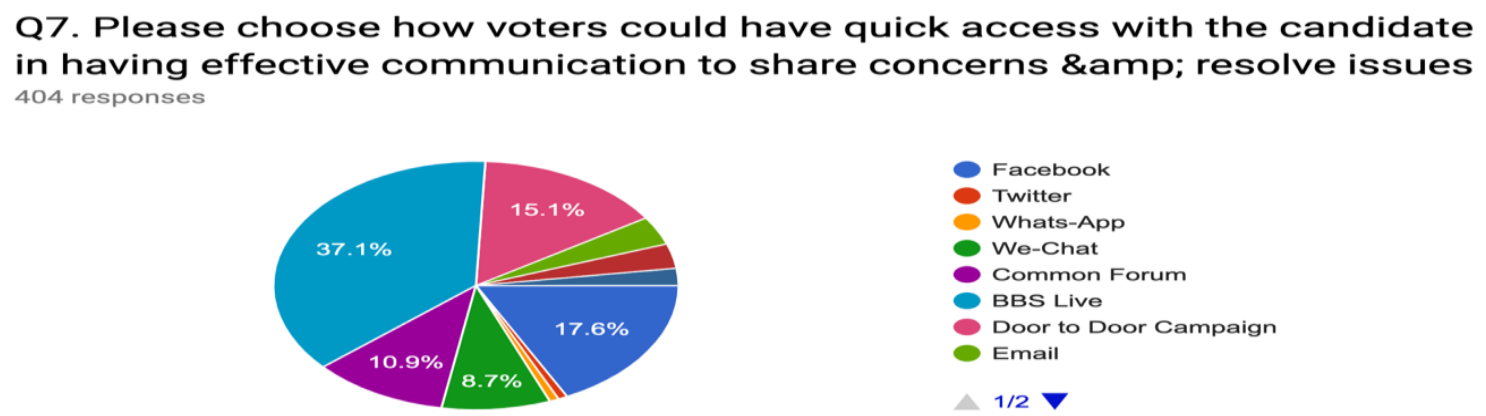

Figure 7; Voters choice towards their communication

channel

Sources; (Author,2019)

Asper the behavior segmentation towards having effective communication channel to share concerns, issues, and resolve the public problems. Out of 404 respondents, 37.1\% choose BBS live, 15.1\% choose door to door campaign, 17.6\% choose Facebook, $10.9 \%$ choose common forum, $8.7 \%$ choose email. So, the author choose to resolve their issues through both digital and traditional marketing strategy

The segmentation for candidate market is as entailed through the following table

Table 1.18 Market Segmentation political candidate

\begin{tabular}{|l|l|l|}
\hline Demographic Segmentation & $\begin{array}{l}\text { Age group 18 years and above with all } \\
\text { occupations, Gender (Both male and female) }\end{array}$ \\
\hline Geographic Segmentation & $>\begin{array}{l}\text { The resident of district which consist of village, } \\
\text { sub-district and district }\end{array}$ \\
\hline Psychographic Segmentation & $\begin{array}{l}\text { The electorates and general public that are } \\
\text { aware of their problems and needs and wants } \\
\text { and are willing to accept the candidate offer }\end{array}$ \\
\hline Behavioral Segmentation & $\begin{array}{l}\text { The electorates and public that seeks for their } \\
\text { benefits and the voter's choice towards } \\
\text { effective communication channel to reach them }\end{array}$ \\
\hline
\end{tabular}




\section{International Journal of Engineering Applied Sciences and Technology, 2021 \\ Vol. 6, Issue 2, ISSN No. 2455-2143, Pages 111-127 \\ Published Online June 2021 in IJEAST (http://www.ijeast.com)}

\section{Targeting}

The potential target market for the candidate will be 18 years and above of both gender and all the occupations in Chukha district Bhutan who vote for election but are of concern about the getting good profile candidate to the post and are willing to vote for the author as a candidate. Since the market research shows that as a candidate, they need a candidate who could realize their needs and wants, their problems, their benefits and choose effective communication channel to reach them in solving those issues and fulfil their needs and wants. Therefore, the candidate will focus on delivering their needs and wants, their benefits and solve the problem as a candidate pledges

\section{Positioning}

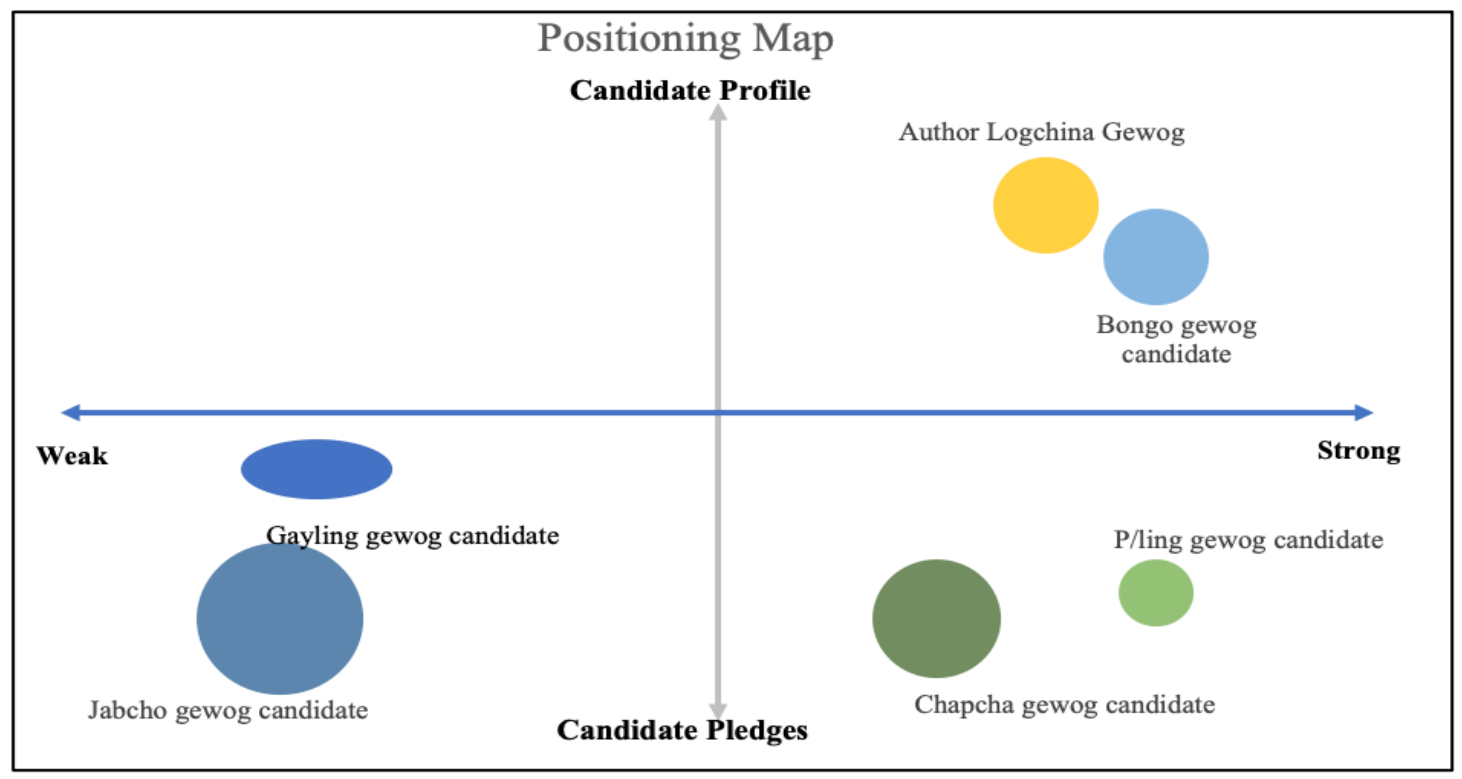

Sources; (Author,2019)

Above all, the pledges of a candidate as an author are based on the roles and responsibilities of national council, based on capacity and potential and the pledges to fulfil the public needs and wants and to resolve the public issues. Through competitive analysis, the candidate position as strong candidate profile \& pledges in a market comparing to other rivals.

\section{COMPETITIVE AANALYSIS}

The following is competitive analysis of candidate with other rivals. It shows the weighted score according to strength and weakness of competitors and the weightage is done on the basis of key factor for success. A score of 4 is strong and 1 represents the weak point.

Table 4: Competitive Profile Matrix for candidate

\begin{tabular}{|c|c|c|c|c|c|c|c|c|c|c|c|c|c|}
\hline \multirow[b]{2}{*}{$\begin{array}{c}\text { Critical } \\
\text { Success Factor }\end{array}$} & \multirow[b]{2}{*}{ Weight } & \multicolumn{2}{|c|}{$\begin{array}{l}\text { Author logchina } \\
\text { gewog }\end{array}$} & \multicolumn{2}{|c|}{$\begin{array}{l}\text { Chapcha gewog } \\
\text { candidate }\end{array}$} & \multicolumn{2}{|c|}{$\begin{array}{l}\text { Phuentsholing } \\
\text { gewog candidate }\end{array}$} & \multicolumn{2}{|c|}{$\begin{array}{l}\text { Jabcho gewog } \\
\text { candidate }\end{array}$} & \multicolumn{2}{|c|}{$\begin{array}{l}\text { Gayling gewog } \\
\text { candidate }\end{array}$} & \multicolumn{2}{|c|}{$\begin{array}{c}\text { Bongo gewog } \\
\text { candidate }\end{array}$} \\
\hline & & Score & $\begin{array}{l}\text { Weighted } \\
\text { Score }\end{array}$ & Score & $\begin{array}{c}\text { Weighted } \\
\text { Score }\end{array}$ & Score & $\begin{array}{l}\text { Weighted } \\
\text { Score }\end{array}$ & Score & $\begin{array}{l}\text { Weighted } \\
\text { Score }\end{array}$ & Score & $\begin{array}{l}\text { Weighted } \\
\text { Score }\end{array}$ & Score & $\begin{array}{l}\text { Weighted } \\
\text { Score }\end{array}$ \\
\hline $\begin{array}{c}\text { Candidate } \\
\text { pledges }\end{array}$ & 0.25 & 3 & 0.75 & 1.6 & 0.40 & 2 & 0.4 & 2 & 0.4 & 2 & 0.25 & 3 & 0.25 \\
\hline $\begin{array}{c}\text { Candidate } \\
\text { qualification }\end{array}$ & 0.25 & 3 & 0.75 & 3 & 0.75 & 3 & 0.4 & 2 & 0.75 & 2 & 0.62 & 3 & 0.25 \\
\hline Candidate PR & 0.25 & 3 & 0.75 & 1.3 & 0.33 & 2 & 0.25 & 3 & 0.4 & 1.3 & 0.75 & 2 & 0.4 \\
\hline $\begin{array}{l}\text { Candidate } \\
\text { experience }\end{array}$ & 0.1 & 4 & 0.40 & 3 & 0.30 & 1.8 & 0.4 & 2 & 0.3 & 1.8 & 0.55 & 1.3 & 0.75 \\
\hline $\begin{array}{l}\text { Candidate } \\
\text { marketing }\end{array}$ & 0.1 & 4 & 0.40 & 3 & 0.30 & 3 & 0.3 & 1.9 & 0.33 & 2 & 0.33 & 2 & 0.4 \\
\hline TOTAL Score & 0.95 & & 3.05 & & 2.08 & & 1.75 & & 2.18 & & 2.5 & & 2.05 \\
\hline
\end{tabular}




\section{The marketing mix 7P's}

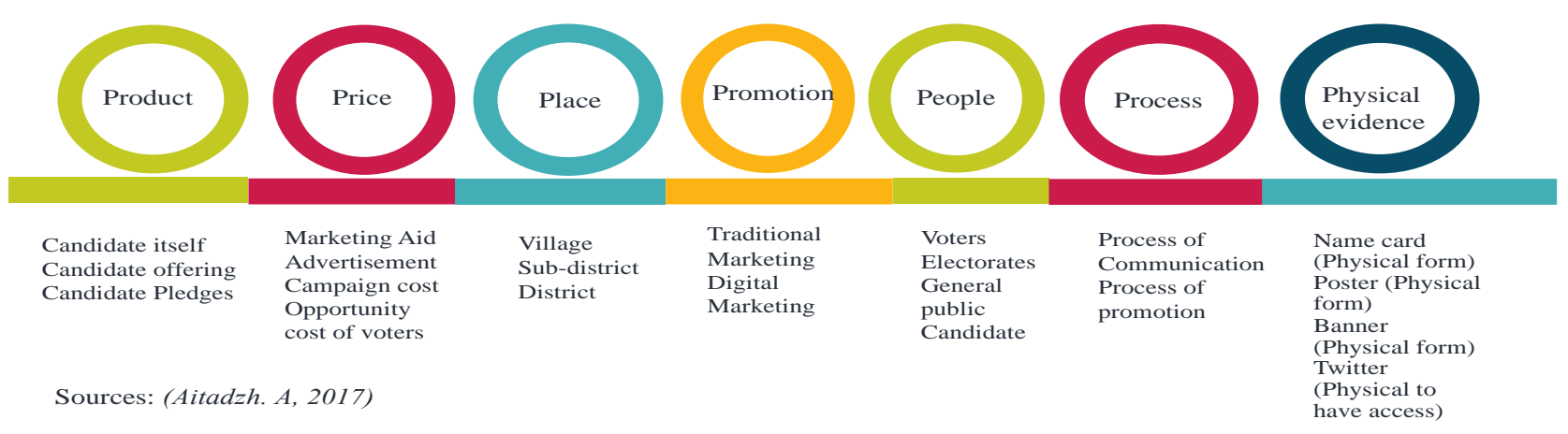

The marketing mix is a strategy tools for the formulation of strategy to promote the candidate as brand and product in a market; The afore diagram is the holistic approach of how the 7p's is derived and interpreted in political marketing

VIII. THE RESEARCH FINDINGS

Key findings of research

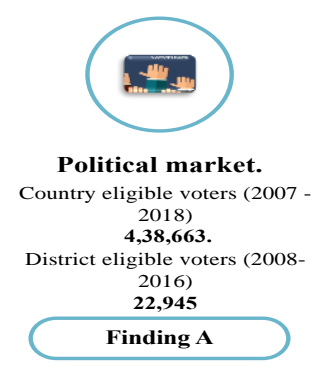

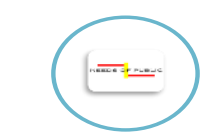

Public needs \& wants.

Candidate profile

Candidate pledges

Finding B

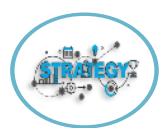

Promotional strategy.

Traditional marketing strategy

Digital marketing strategy.

Finding C

Sources; (Author,2019)

The research findings are well aligned with the research objectives. It has three core findings. The political market, public needs and wants and promotional strategy. Every finding has been derived through empirical research and data driven decision making. Those finding would serve as a guiding tool for the candidate as a product and brand to promote in a market 


\section{International Journal of Engineering Applied Sciences and Technology, 2021 \\ Vol. 6, Issue 2, ISSN No. 2455-2143, Pages 111-127 \\ Published Online June 2021 in IJEAST (http://www.ijeast.com)}

\section{REFERENCES}

[1] Amable, T.(2018, May 16). The importance of PESTEL analysis. Retrieved May 3, 2019, from https://www.girlfridayz.com/post/the-importance-of-apestel-analysis

[2] Analyst zone. (2018, July 2). The MOSCOW analysis prioritization and scoping. Retrieved April 6, 2019, from https://www.youtube.com/watch?v=kDg-AkvkBtE

[3] Council foreign relation. (2019). The Bhutan's road map towards democratic system. Retrieved from https://www.cfr.org/interview/bhutans-road-democracy

[4] Clegg, D. (2019). The description of MOSCOW. Tools hro.com. Retrieved from https://www.toolshero.com/project-management/moscowmethod/

[5] Davidson,S., \& Binstock, R. (2011). Political marketing and segmentation in aging democracies from: Routledge Handbook of Political Marketing Routledge. Retrieved March 5,2019, from file://Users/damchogyeltshen/Downloads/RoutledgeHand books-9780203349908-chapter3.pdf

[6] Durcevic, S. (2019, April 16). The data driven decision making. $\quad$ Retrieved from https://www.datapine.com/blog/data-driven-decisionmaking-in-businesses/

[7] Durmaz, Y., \& Direkci, E. (2015). Theoretical approach to political marketing.

Journal of management \& business research, 15(10), 09755853. Retrieved July 4, 2019, from file://Users/damchogyeltshen/Downloads/1881-1-1860-110-20160225\%20(4).pdf

[8] Economic times. (2018). The pricing strategies form economic times . Retrieved May 4, 2019, from https://economictimes.indiatimes.com/definition/pricingstrategies?from $=\mathrm{mdr}$

[9] Haughey, D. (2019). The MOSCOW prioritization analysis technique. Retrieved May 3, 2019, from https://www.projectsmart.co.uk/moscow-method.php

[10] Harris, B. (2019). The democratic countries in a world according to economist. The world economic forum. Retrieved August 4, 2019, from https://www.weforum.org/agenda/2018/02/nordiccountries-top-democratic-rankings-2017/
[11] Jack Ma. (2018, March). The hidden opportunities that leads to key success. Retrieved April 6, 2019, from https://medium.com/@shahmm/unravelling-the-hiddenopportunities-that-influenced-jack-ma-s-success$3 \mathrm{a} 1125 \mathrm{~b} 4 \mathrm{~d} 4 \mathrm{cf}$

[12] Kokemuller, N. (2019, August 7). The STP analysis and its implication to business. Retrieved June 9, 2019, from https://yourbusiness.azcentral.com/stp-marketing1769.html

[13] National Council of Bhutan. (2019). About National Council of Bhutan . Retrieved July 2, 2019, from https://www.nationalcouncil.bt/en/about/national-council

[14] National assembly of Bhutan. (2019). About National Assembly of Bhutan. Retrieved March 3, 2019, from http://www.nab.gov.bt/en/about/national-assembly

[15] Pet therapy. (n.d). The PESTEL analysis. professional academy. Retrieved June 4, 2019, from https://www.professionalacademy.com/blogs-andadvice/marketing-theories---pestel-analysis

[16] Suradech, W. (2017, October 16). SWOT analysis. Retrieved $15 \quad$ August, 2019, from https://www.ceoblog.co/what-is-swot-analysis/

[17] Thompson, J.(2018). The STP marketing meaning and its significance. Retrieved March 5, 2019, from https://bizfluent.com/info-8693419-stp-marketing.html

[18] Vohra, G.(2018, November 30). The description of analytical tools. Analytical training.com. Retrieved June 6, 2019, from https://analyticstraining.com/10-mostpopular-analytic-tools-in-business 